\section{General Electric Co., Ltd.}

Mr. O. W. Humphreys and Mr. A. L. G. Lincley have been appointed to the board of directors of the General Electric Co., Ltd., London. Mr. Humphreys, who is director of the Research Laboratories of the Company at Wembley, Middlesex, joined the staff of the Laboratories in 1925, and in 1927 was appointed to its leading scientific staff in charge of the heat group. $\mathrm{He}$ is a vicepresident of the Institute of Physics and of the Institution of Electrical Engineers. Mr. Lindley joined Fraser and Chalmers Engineering Works in 1918 as on apprentice, and after spending some years as an assistant engineer in the Mining Department was appointed in 1932 chief engineer of the British General Electric Co., Ltd., of South Africa. Returning to England in 1949, he became general manager of the Fraser and Chalmers Engineering Works.

\section{British North Greenland Expedition}

For the third year in succession, the Royal Air Force will undertake a series of flights within the Arctic Circle to assist the British North Greenland Expedition. This year's flights, which are required to carry stores for the Expedition, will be made in August by five Sunderland flying-boats of Coastal Command and two Hastings aircraft of Transport Command. On August 1, five Sunderlands of No. 201 Squadron will leave R.A.F. Station, Pembroke Dock, South Wales, for Greenland. Their base will be at Young Sound, on the north-east coast (lat. $74^{\circ} 29^{\prime}$ N., long. $20^{\circ} 40^{\prime}$ W.), to which the Expedition ship, the Polarsirkel, will deliver the stores. On August 5 the Sunderlands will start to fly seventy tons of stores to the Expedition's main camp at Britannia Lake (lat. $77^{\circ} 07^{\prime} \mathrm{N}$., long. $23^{\circ} 40^{\prime}$ W.), some 190 miles from Young Sound. The task should be completed in seven to ten days. In mid-August, two Hastings aircraft will leave R.A.F. Station, Abingdon, Berks, for the United States Air Force base at Thule, in north-western Greenland. Their task is to drop some sixty tons of supplies, chiefly petrol, for the 'weasel' tracked vehicles, to the existing advanced camp at position lat. $78^{\circ} 02^{\prime} \mathrm{N}$., long. $37^{\circ} 50^{\prime} \mathrm{W}$., now known as 'Northice', and also to establish a petrol dump in a position 200 miles to the west of Northice. The supply drops are due to start on August 20, and should be completed in about ten days; sugar, milk powder and miscellaneous items will also be dropped.

The Royal Air Force made the first flights for the British North Greenland Expedition in July 1951 , when a preliminary survey of the ice-cap was made. In 1952, between August and October, five Sunderlands and two Hastings, with a total crew complement of 87 officers and airmen, carried 250 tons of equipment to help the Expedition establish bases. These air operations, apart from making an essential contribution to the success of the Expedition, proved of considerable training value to the R.A.F., since aircrews gained valuable experience in high-latitude navigation and cold-weather flying. The British North Greenland Expedition, of which the Queen is Patron, is undertaking a geophysical, geological and glaciological survey of hitherto unexplored areas of northern Greenland. One of the objects is to establish the depth of the great ice-cap which covers most of the country. The Expedition has now moved its 'weasels' over a glacier to the main base at Britannia Lake, and has relieved the original party of three which occupied the advanced camp at 'Northice'. The 'weasels' are now operating over the ice-cap, and the general field work of the Expedition is progressing according to plan.

\section{Science in Education}

IN a speech before Timsbury County Secondary School on June 23, Prof. John Read, professor of chemistry in the University of St. Andrews, claimed that the teaching of mathematics and science should also train students to be exact, accurate, logically minded and precise in the expression of thought. The teaching of science should go still further in encouraging accurate observation and correct interpretation. The three main pillars of education, in spite of the present-day tendency to multiply subjects and introduce more work of a practical nature, are still the three R's : reading, in order to give good command of English; writing, to confer an ability to express ideas clearly and concisely ; arithmetic, as the basis of a sound grounding in elementary mathematics. The ideal education should hold a proper balance between science and the arts. Science in itself contributes much to a cultural education. For example, it is difficult to consider a person as being properly educated or cultured who has no basic knowledge of what goes on in the world of Nature around him and also within himself. There are, of course, dangers in a purely scientific education in which a pupil may be overloaded with factual information or furnished with an account of the world which overlooks the moral aspect of the mind. There are plenty of reference libraries available, and this should be recognized together with Plutarch's dictum : "The child's mind is not a vessel to be filled, but a fire to be kindled". In brief, it must be realized that science has its limits as an educative and cultural instrument; but it must be acknowledged that to-day a certain broad acquaintance with science is essential in a world where science has such a profound influence on society and confers so much physical power on man.

\section{Lighter Literature for the Medical Man}

$A$ Medical Bulletin, described as "a journal for the profession" and published by Messrs. May and Baker, Ltd., is a periodical different from most of the literature produced specifically for medical men's eyes and minds. Not all doctors will like all of it, but there is little doubt that many doctors must find in it relaxation and a lighter handling of serious subjects, which is often refreshing and sometimes both refreshing and instructive at the same time. It is possible, as several writers in this journal show, to write about grave matters with a disciplined sense of humour which, if it does not convey the facts of which the doctor sometimes gets too many, illuminates the subject from unusual points of view, so that new and instructive aspects of it become evident. This, however, is a difficult art. It is so easy to do no more than reproduce a manner of writing too reminiscent of the medical students' magazines to which many of the adult readers of this Bulletin probably contributed. The Bulletin also contains some interesting and attractively written articles which are not specifically medical. Those, for example, on the development of the small house in England, which are so charmingly illustrated, would win the heart of any reader or editor; and in the series on the doctor's helpmates, the doctor's wife, who does so much and gets so little public regard, 